\title{
OPTICAL MICROSCOPY AND SEM FOR IDENTIFYING CLOGGING MATERIAL IN A DRIP IRRIGATION SYSTEM ${ }^{1}$
}

\author{
MAYCON DIEGO RIBEIRO ${ }^{2 *}$, CARLOS ALBERTO DE AZEVEDO ${ }^{3}$, DELFRAN BATISTA DOS SANTOS ${ }^{4}$, FLAVIO \\ DANIEL SZEKUT ${ }^{5}$, MÁRCIO ROBERTO KLEIN ${ }^{3}$, CLAUDIA FACINI REIS $^{6}$
}

\begin{abstract}
The aim of this study was to apply optical microscopy and scanning electron microscopy (SEM) techniques to identify and assess dripper clogging of an irrigation system. Three dripper models (Taldrip, Streamline, and Tiran) underwent 1200 hours of irrigation with three types of effluents: treated domestic wastewater, water with a high calcium content, and urban water supply. Samples of the material adhered to the inside of drippers were analyzed by means of the smear method aiming at their biological identification. Other samples were taken to obtain SEM images. The presence of algae, bacteria, and biological components of biofilm was observed in drippers operating with wastewater and water with calcium, this latter in a low number. The formation of biofilm and chemical precipitates of calcium were observed in SEM images, leading to emitter clogging. Optical microscopy and SEM analyses allowed identifying the degree of fouling by biofilm and chemical precipitates in dripper clogging.
\end{abstract}

Keywords: Clogging. Water. Irrigation system drippers.

\section{MICROSCOPIA ÓPTICA E MEV NA IDENTIFICAÇ̃̃O DE MATERIAL OBSTRUIDOR DE GOTEJADORES EM SISTEMA DE IRRIGAÇÃO LOCALIZADA}

RESUMO - O objetivo da pesquisa foi aplicar as técnicas de microscopia óptica e Microscopia Eletrônica de Varredura (MEV) para identificar e avaliar os causadores da obstrução dos gotejadores de irrigação localizada. Três modelos de gotejadores (Taldrip, Streamline e Tiran) foram submetidos a 1200 horas de irrigação com três tipos de efluentes: água residuária de esgoto doméstico tratado água com elevado teor de cálcio e água de abastecimento urbano. Amostras do material aderida no interior dos gotejadores foram analisadas pelo método de esfregaço para fazer a identificação biológica, outras amostras foram retiradas para realizar as imagens com MEV. Foi possível verificar a presença de algas, bactérias e componentes biológicos do biofilme, tanto nos gotejadores operando com água residuária, quanto naqueles que operavam com água com cálcio, esta última em menor quantidade. Nas imagens com MEV foi possível verificar a formação de biofilme que causou a obstrução dos emissores e também os precipitados químicos de cálcio. A análise por MEV e microscopia óptica permitiu identificar o grau de incrustação por biofilme e precipitados químicos na obstrução de gotejadores.

Palavras-chave: Obstrução. Água. Gotejadores de irrigação localizada.

\footnotetext{
${ }^{*}$ Corresponding author

${ }^{1}$ Received for publication in 07/11/2017; accepted in 04/19/2018

Paper extracted from the doctoral thesis of the first author.

${ }^{2}$ Advanced Campus of Jandaia do Sul, Universidade Federal do Paraná, Jandaia do Sul, PR, Brazil; ribeiro.md@gmail.com - ORCID: 0000 $-0002-9311-5944$.

${ }^{3}$ Center for Technology and Natural Resources, Universidade Federal de Campina Grande, Campina Grande, PB, Brazil; cvieiradeazevedo@gmail.com - ORCID: 0000-0001-7336-1243, engmarcioklein@gmail.com - ORCID: 0000-0002-2820-772X.

${ }^{4}$ Instituto Federal de Educação, Ciencia e Tecnologia Baiano, Salvador, BA, Brazil; delfran.batista@gmail.com - ORCID: 0000-0003-0670 $-9689$.

${ }_{5}^{5}$ Departament of Agronomy, Faculdade Educacional de Francisco Beltrão, Francisco Beltrão, PR, Brazil; flaviodanielszekut@gmail.com ORCID: 0000-0003-1028-9074.

${ }^{6}$ INSA, Instituto Nacional do Semiárido, Campina Grande, PB, Brazil; reisfe@gmail.com - ORCID: 0000-0002-8948-4974.
} 
M. D. RIBEIRO et al.

\section{INTRODUCTION}

Water is an essential factor for irrigation, being the main input used, but its quality is variable since it comes from different sources and has different characteristics (ALMEIDA, 2010). Lowquality irrigation water present problems such as clogging of pipes and drippers, affecting not only the system but also agricultural production, with economic losses to farmers (GHUNMI et al., 2009). A water source that has been used for irrigating economically exploited crops, mainly in arid and semi-arid regions, is the wastewater from domestic sewage (ALMEIDA, 2010).

Other common sources of water used in irrigation are those with a high content of salts such as sodium, calcium, and magnesium in the form of chlorides, sulfates, and bicarbonates, and in relatively low proportions potassium and carbonate (SILVA et al., 2011). According to Cavalcante (2000), in chemical terms, a quality water for irrigation is determined by the composition and concentrations of salts constituted and dissolved in it since they can cause chemical precipitation and consequent dripper clogging.

According to Batista, Souza and Ferreira (2010), the application of treated domestic wastewater has a potential for dripper clogging due to biofilm formation by the interaction between bacterial and algae colonies, causing a partial or total clogging with distribution efficiency loss. Vale et al. (2013) observed a reduction in the hydraulic performance of a drip irrigation system when using different concentrations of domestic wastewater with primary treatment diluted in the water supply. Drip irrigation systems are extremely susceptible to clogging, and even with a filtration process to retain solid particles, precipitates may be formed inside the pipes, causing a physical clogging.

For a better assessment and characterization of microscopic material from any origin and that causes clogging or not, it is possible to use optical and scanning microscopy techniques with efficiency for assessing biological materials (SCHONHERR; VANCSO; ARGON, 1995; HERRMANN et al., 1997). Similarly, Sant'Anna (2005) and Toma and Araki (2005) noticed that biological assessments that use innovative or even already known technologies applied to new science goals are promising techniques capable of obtaining results not yet achieved.

Thus, it is necessary to know and identify how the material that precludes the passage of water through the orifice at a microscope level is formed in order to carry out suitable treatments of unclogging. The aim of this study was to identify and assess the clogging material of the dripping tube by means of optical microscopy and scanning electron microscopy (SEM).

\section{MATERIAL AND METHODS}

The experiment was carried out at the National Institute for the Semiarid Region (INSA), located in Campina Grande, PB, Brazil, with geographical coordinates of $7^{\circ} 16^{\prime} 20^{\prime \prime} \mathrm{S}$ and $35^{\circ} 56^{\prime}$ $29^{\prime \prime} \mathrm{W}$ and an altitude of $550 \mathrm{~m}$. According to Köeppen's classification, regional climate is type As. The experiments were installed on a test bench of 10 $\times 2 \times 1.2 \mathrm{~m}$ (length $\times$ width $\times$ height $)$ with collecting gutters that recirculated water. The system consisted of support trestles, zinc gutters, and supporting arches of the lateral dripper lines; water reservoirs; pipes and fittings; LAO ${ }^{\circledR}$ hydrometer model UJB1, with a nominal flow of $1.5 \mathrm{~m}^{3} \mathrm{~h}^{-1}$ to measure the volume and water flow of the system; IRRITEC ${ }^{\circledR}$ 200-mesh disc filters model FLD; 1" gate valve; BERMAD $^{\circledR}$ direct-acting pressure controllers model 0075 PRVy for system pressure control; GE glycerin -filled Bourdon tube pressure gauges with a $0.10 \mathrm{~kg}$ $\mathrm{cm}^{-2}$ resolution for system pressure gauging; and connectors and lateral dripper lines.

Three irrigation systems were installed on the experimental bench by using effluents with different qualities: (i) supply water, (ii) treated domestic wastewater, and (iii) water with a high calcium content (we added $1.0 \mathrm{~g} \mathrm{~L}^{-1}$ hydrated lime with about $10 \%$ calcium carbonate $\left[\mathrm{CaCO}_{3}\right]$ and $90 \%$ calcium hydroxide $\left[\mathrm{Ca}(\mathrm{OH})_{2}\right]$, which reacted with water and formed calcium precipitates in the form of carbonates). Three models of dripper tubes were used: Naadanjain Taldrip, Netafim Strenline 16080, and Netafim Tiran 16010 (Table 1), which operated during 1200 hours and were tested with the three water qualities.

Table 1. Dripper characteristics.

\begin{tabular}{ccccc}
\hline Brand & Model & $\begin{array}{c}\text { Flow rate } \\
\left(\mathrm{L} \mathrm{h}^{-1}\right)\end{array}$ & Pressure (kPa) & Drip spacing (m) \\
\hline NAADANJAIN & Taldrip & 1.70 & 100 & 0.20 \\
NETAFIM & Streamline 16080 & 1.60 & 100 & 0.30 \\
NETAFIM & Tiran 16010 & 2.00 & 100 & 0.40 \\
\hline
\end{tabular}




\section{Characterization of clogging material}

The clogging material formed by water supply, wastewater, and water with a high calcium content were analyzed and characterized by the taxonomic identification of microorganisms in the sample, used mainly for clogging with wastewater. SEM analyses were also carried out to identify the structures and shapes of material adhered to dripper walls.

\section{Taxonomic identification of clogging material by optical microscopy}

Water samples were collected, identified, and stored following the standard NBR 9898/85 for taxonomic identification of organisms present in water. These samples were taken from the inside of dripper tubes and placed in plastic containers to perform the microscopic assessment using a simple pipette and a microscope slide.

The procedure consisted of collecting $1 \mathrm{~mL}$ of sample with a pipette and placing it on the microscope slide by means of the smear technique, which consists of spreading the sample onto the slide with a spatula. This procedure was performed in triplicate. In addition to the smear technique, the technique of simple slide heated in Bunsen beak was performed until the total water evaporation on the slide. No dyes nor neutralizing or fixing substances were used.

After preparation and identification of slides, a Leica ${ }^{\circledR}$ optical microscope was used to visualize the slides at 4, 10, 40, and 100x magnification. The visualization technique was to read transects from the beginning to the end of the sample in all triplicates.

The digital photographic record of the main visualizations of bacterial colonies, isolated bacteria, and other identified microorganisms was carried out in the microscopic assessment. For identification on a genus scale, the taxonomic key technique and a subsequent comparative table of images were used.

\section{Analyses of clogging material by SEM images}

For sample analyses with SEM equipment, a channel was removed from the emitter flow path of each dripper tube model after clogging process, in which the existing chemical elements in the clogging material were verified.

To improve the level of electron emission, samples were submitted to a metallization process with gold metal ions and placed in a chamber with a pressure of 0.1 to 0.05 mbar. The metal target is bombarded with inert gas atoms and the target atoms are deposited on the sample.

\section{RESULTS AND DISCUSSION}

\section{Characterization of different water quality}

Water analysis to characterize the chemical and microbiological parameters of the supply water, treated domestic wastewater, and water with calcium used in the experiments are shown in Tables 2 and 3. Table 2 shows some values that are out of the established standards for water quality for irrigation. According to Ayers and Westcot (1991) and Aragués et al. (1979), the $\mathrm{pH}$ of water with calcium $(\mathrm{pH}=9)$ is considered of high risk of clogging due to chemical precipitation of carbonates and bicarbonates. According to Nakayama (1982), pH values of drip irrigation water above eight is considered of severe risk of dripper clogging. Moreover, for the three water types, clogging risk is considered as moderate in relation to total dissolved solids, which has a range for this classification between 500 and $2000 \mathrm{mg} \mathrm{L}^{-1}$.

According to Pizarro (1996), the main lowsolubility salts with the highest capacity to precipitate and, consequently, with the highest clogging risk to irrigation drippers are calcium and magnesium carbonates. As shown in Table 2, calcium hardness values are 26,48 , and $79 \mathrm{mg} \mathrm{L}^{-1}$ respectively for supply water, wastewater, and water with calcium. The highest risk of chemical clogging was observed for water with calcium in relation to hardness values and precipitates of calcium carbonate. This risk is aggravated when associated with a high $\mathrm{pH}$ value.

Another factor related to calcium precipitates is the Langelier saturation index (LSI) (NAKAYAMA; BUCKS, 1986), in which positive values indicate a risk of calcium carbonate precipitation in irrigation water. Thus, Table 2 shows that the risk caused by calcium carbonate precipitates exists only for water with calcium, which presented an LSI value of 1.81. For water supply and wastewater, this value was negative, presenting no risk of clogging. 
M. D. RIBEIRO et al.

Table 2. Chemical characterization of effluents.

\begin{tabular}{lccc}
\hline \multirow{2}{*}{ Parameter } & \multicolumn{3}{c}{ Result } \\
\cline { 2 - 4 } & Water supply & Wastewater & Water with calcium \\
\hline Electrical conductivity $\left(\mathrm{mmho} / \mathrm{cm}\right.$ at $\left.25^{\circ} \mathrm{C}\right)$ & 1092.00 & 2139.00 & 2860.00 \\
$\mathrm{pH}$ & 6.60 & 7.60 & 9.00 \\
Turbidity (uT) & 0.70 & 3.30 & 5.20 \\
Color, Hazen Unit $(\mathrm{mg}$ Pt-Co/L) & 0.00 & 110.00 & 100.00 \\
Calcium hardness $(\mathrm{mg} / \mathrm{L})$ & 26.60 & 48.00 & 79.50 \\
Magnesium hardness (mg/L) & 35.00 & 37.20 & 30.00 \\
Total hardness (mg/L) & 212.50 & 275.70 & 323.80 \\
Sodium (mg/L) & 148.90 & 234.70 & 521.80 \\
Potassium (mg/L) & 5.30 & 60.60 & 8.20 \\
Aluminum (mg/L) & 0.13 & 0.09 & 0.00 \\
Total iron (mg/L) & 0.01 & 0.08 & 0.08 \\
Alkalinity in hydroxides $(\mathrm{mg} / \mathrm{L})$ & 0.00 & 0.00 & 0.00 \\
Alkalinity in carbonates $(\mathrm{mg} / \mathrm{L})$ & 0.00 & 0.00 & 210.00 \\
Alkalinity in bicarbonates $(\mathrm{mg} / \mathrm{L})$ & 84.00 & 203.20 & 85.00 \\
Total alkalinity (mg/L) & 84.00 & 203.20 & 295.00 \\
Sulfate $(\mathrm{mg} / \mathrm{L})$ & 34.40 & 114.30 & 67.10 \\
Phosphorus Total (mg/L) & 0.00 & 10.70 & 0.00 \\
Chloride (mg/L) & 305.30 & 388.70 & 777.50 \\
Nitrate (mg/L) & 0.04 & 0.66 & 0.75 \\
Nitrite (mg/L) & 0.00 & 0.03 & 0.19 \\
Ammonia (mg/L) & 0.45 & 21.40 & 6.46 \\
Silica (mg/L) & 3.70 & 6.20 & 5.00 \\
LSI (Langelier saturation Index) & -1.57 & -0.02 & 1.81 \\
TDS (total dissolved solids at $\left.180^{\circ} \mathrm{C}\right)(\mathrm{mg} / \mathrm{L})$ & 662.40 & 1160.00 & 1726.20 \\
\hline
\end{tabular}

Other factors of water quality observed were related to microbiological characteristics. As shown in Table 3, total coliform values were 520, 10112 and 10112 colony-forming units (CFU) for water supply, wastewater, and water with calcium, respectively, at the beginning of the experiment.

According to Nakayama (1982), CFU values for water supply do not present a risk of clogging for drip irrigation systems, unlike the values of wastewater and water with calcium, which present a moderate risk of clogging.

Table 3. Microbiological characterization of water samples used in the experiment.

\begin{tabular}{|c|c|c|c|}
\hline \multirow{2}{*}{ Parameter } & \multicolumn{3}{|c|}{ Result } \\
\hline & Water supply & Wastewater & Water with calcium \\
\hline Total coliforms & 520.00 & 10112.00 & 10112.00 \\
\hline Escherichia coli & 0.00 & 9139.00 & 63.00 \\
\hline
\end{tabular}

Figure 1 shows that at some moments of the experiment, the number of coliforms rose, surpassing the value of 100,000 CFU. According to Nakayama
(1982), the risks of clogging irrigation drippers when values exceed 100,000 CFU is considered as moderate to severe.

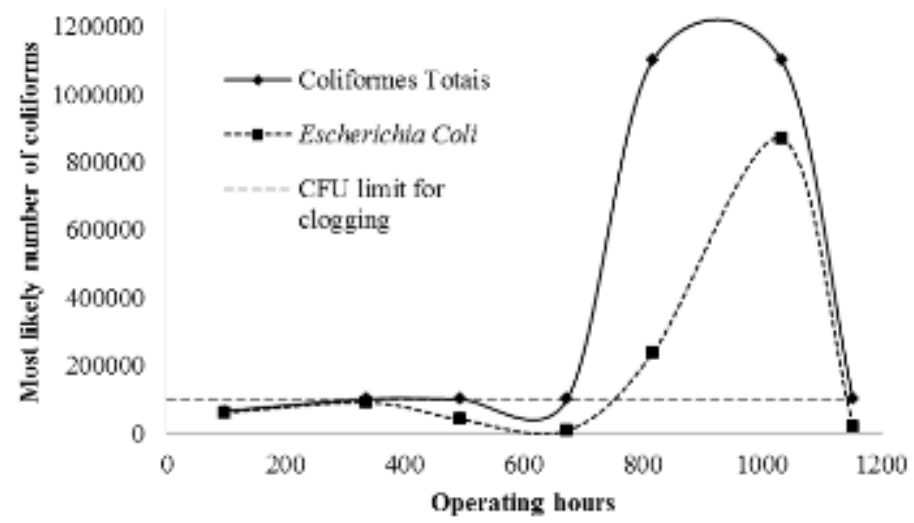

Figure 1. Microbiological monitoring of the number of total coliforms and Escherichia coli during the operation of the experiment with wastewater. 
According to water analyses, irrigation systems tend to be clogged due to irrigation water quality. The system operating with wastewater has a high number of bacterial colony-forming units, which leads to biofilm formation and hence dripper clogging. Experiments operating with calcium excess, high $\mathrm{pH}$, and high Langelier saturation index lead to chemical precipitation and the possibility of dripper clogging.

Once clogged, it is possible to apply unclogging treatments thereafter. However, these water quality standards are not very different from those used by farmers when considering carelessness, because they do not care about these variables, or because they do not have high-quality water supplies.

Microbiological identification of the material adhered to the walls of dripper tubes by using optical microscopy

Through the optical microscopy, we identified the main microbiological components of the biofilm material found inside dripper tubes operated with water supply, wastewater, and water with calcium. Organisms such as unicellular and multicellular algae, cyanobacteria, and bacteria were identified with optical microscopy images of dripper tube material.

\section{Water supply}

Figure 2 shows optical microscopy images of materials adhered in dripper tubes operated with water supply. We identified diatoms probably of the genus Gomphonema sp. (Figure 2A), a small number of fecal coliforms (Figure 2B), chlorophyll algae of the genus Espirogira sp. (Figure 2C), organisms suggestive of helminth eggs (Figure 2E), and bacillary bacteria (Figure 2D). We also identified biofilm formation (Figure 2F) and coccus and colonial bacteria (Figure 2G). Moreover, the presence of fecal coliforms was observed in the sample of material adhered to the dripper tube operated with supply water.

\section{Wastewater}

Samples of wastewater from dripper tubes showed the presence of colonies of bacteria and cyanobacteria such as Microcystis aeruginosa (Figure 3A), with a potential to form biofilm and hence clog irrigation drippers. According to Menezes and Bicudo (2010), these type of bacteria is able to form colonies and, consequently, biofilm by using water substrates.

Figure 3 also shows a group composed of diatom (probably of the genus Gomphonema sp.)
(Figure 3B) and dinoflagellate algae (Figure 3F). These algae have silica in their composition, which can react chemically with other water substances and cause fouling in dripper tubes. Another chlorophyll microorganism of the genus Espirogira was also found (Figure 3C) (MENEZES; BICUDO 2010).

The optical microscopy analysis of wastewater material showed the presence of a large number of fecal coliform bacteria, followed by diatom algae. This is a cause for concern since when coliforms exceed the limit of 100,000 CFU, the risk of clogging the dripper tubes is high (NAKAYAMA, 1982).

\section{Water with calcium}

In the identification by optical microscopy of the material adhered to the dripper tube with calcium -rich water, the organisms were classified as unicellular algae (cyanobacteria), bacteria, helminth eggs, and acariform arachnids (Figure 4).

Dinoflagellates (Figure 4D), fecal coliforms in a low number, biofilm formation, and bacterial colonies of Microcystis aeruginosa (Figure 4C) were found in the samples of water with calcium. Coccus and bacillus bacteria were identified among the organisms of the kingdom Monera. A small-scale presence of fecal coliform microorganisms (Figure 4A) was registered.

\section{Analysis of the clogging material adhered to drippers by SEM}

With the aid of high-resolution and approximation images provided by scanning electron microscopy (SEM), we identified the configurations and formats of the material adhered to the drippers, as well as their structure in the obstruction process.

A biofilm layer was formed on the walls of dripper tubes operated with water supply (Figure 5A, $\mathrm{D}$, and $\mathrm{G}$ ) and wastewater (Figure $5 \mathrm{~B}, \mathrm{E}$, and $\mathrm{H}$ ). However, these layers are more noticeable in dripper tubes operated with wastewater, probably formed by colonies of bacteria and cyanobacteria as identified in optical microscopy images, which partially or totally clogged drippers (MENEZES; BICUDO, 2010).

Figure 5 shows that the internal part of drippers operated with wastewater become smaller as biofilm increased, consequently reducing water passage. Although water supply has formed a biofilm, its amount is lower when compared to that formed with wastewater. According to Batista, Souza and Ferreira (2010), dripper clogging operated with treated domestic wastewater is caused by biofilm, a result of the interaction between colonies of bacteria and algae, occurring partial or total dripper clogging. 


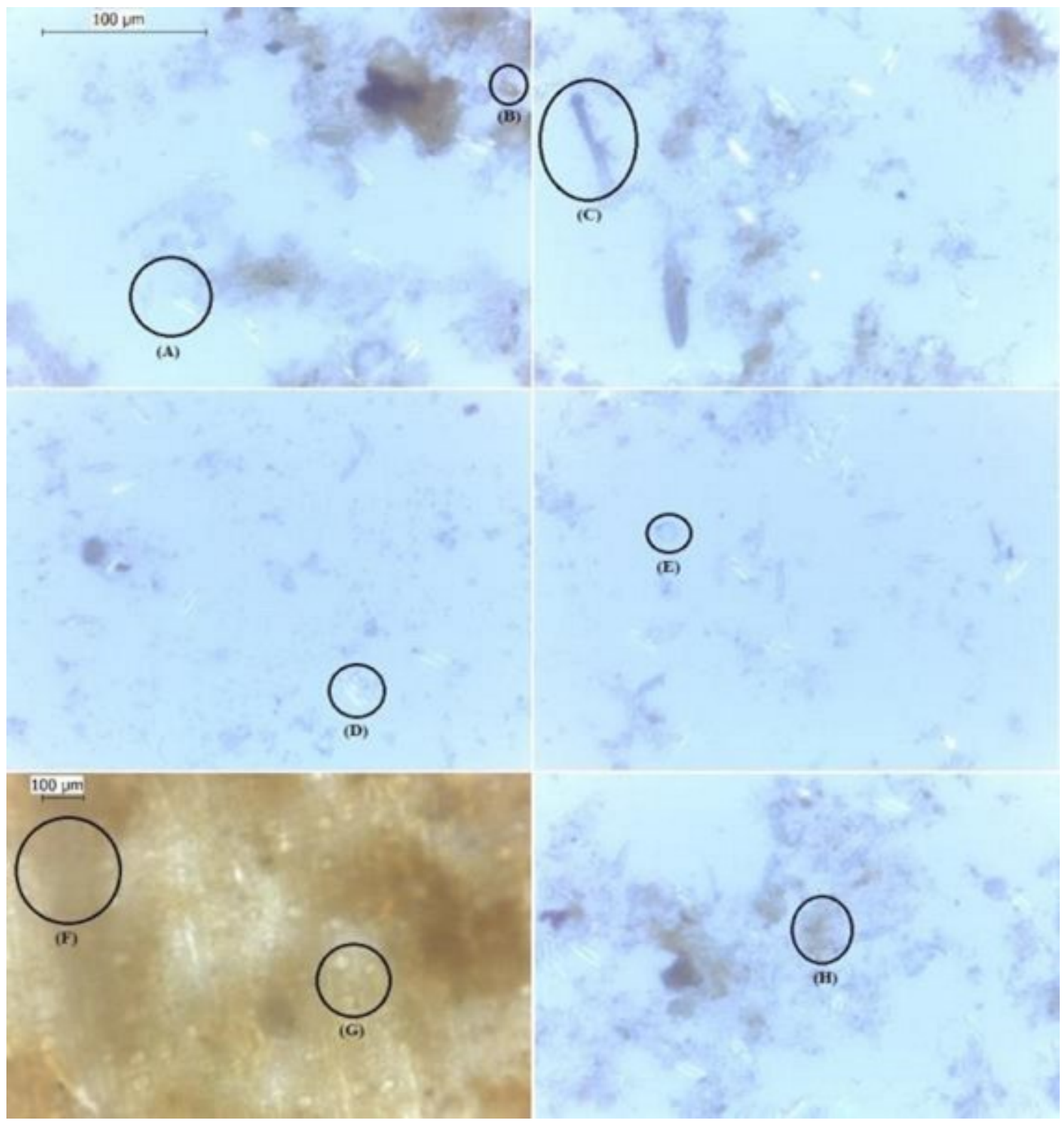

Figure 2. Identification of the main microbiological components in the inside of dripper tubes operated with water supply: (A) diatoms probably of the genus Gomphonema sp.; (B) fecal coliforms; (C) chlorophyll algae of the genus Espirogira sp.; (D) asexual reproduction by duplication in bacillary bacteria; (E) suggestive form of Ascaris lumbricoides egg; (F) biofilm formation; $(\mathrm{G})$ suggestive form of coccus bacteria; $(\mathrm{H})$ Microcystis aeruginosa colony. 


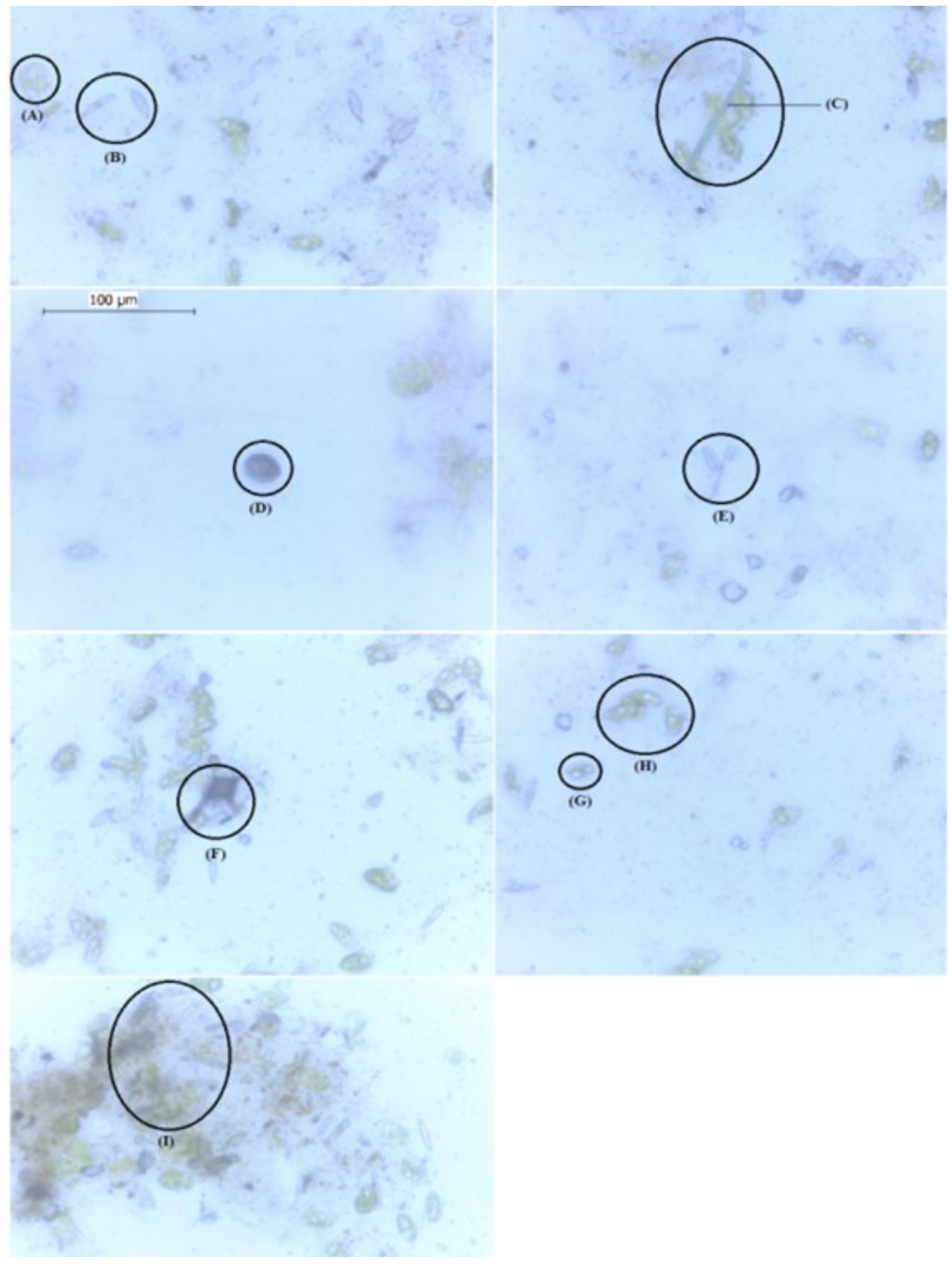

Figure 3. Identification of the main microbiological components in the inside of dripper tubes operated with wastewater: (A) Microcystis aeruginosa colony; (B) diatoms probably of the genus Gomphonema sp. (C); chlorophyll algae probably of the genus Espirogira sp.; (D) egg of Ascaris lumbricoides (E); asexual reproduction by duplication in bacillary bacteria; (F) chlorophyll algae (probably dinoflagellate); $(\mathrm{G})$ coccus bacteria; $(\mathrm{H})$ fecal coliforms; (I) biofilm formation. 


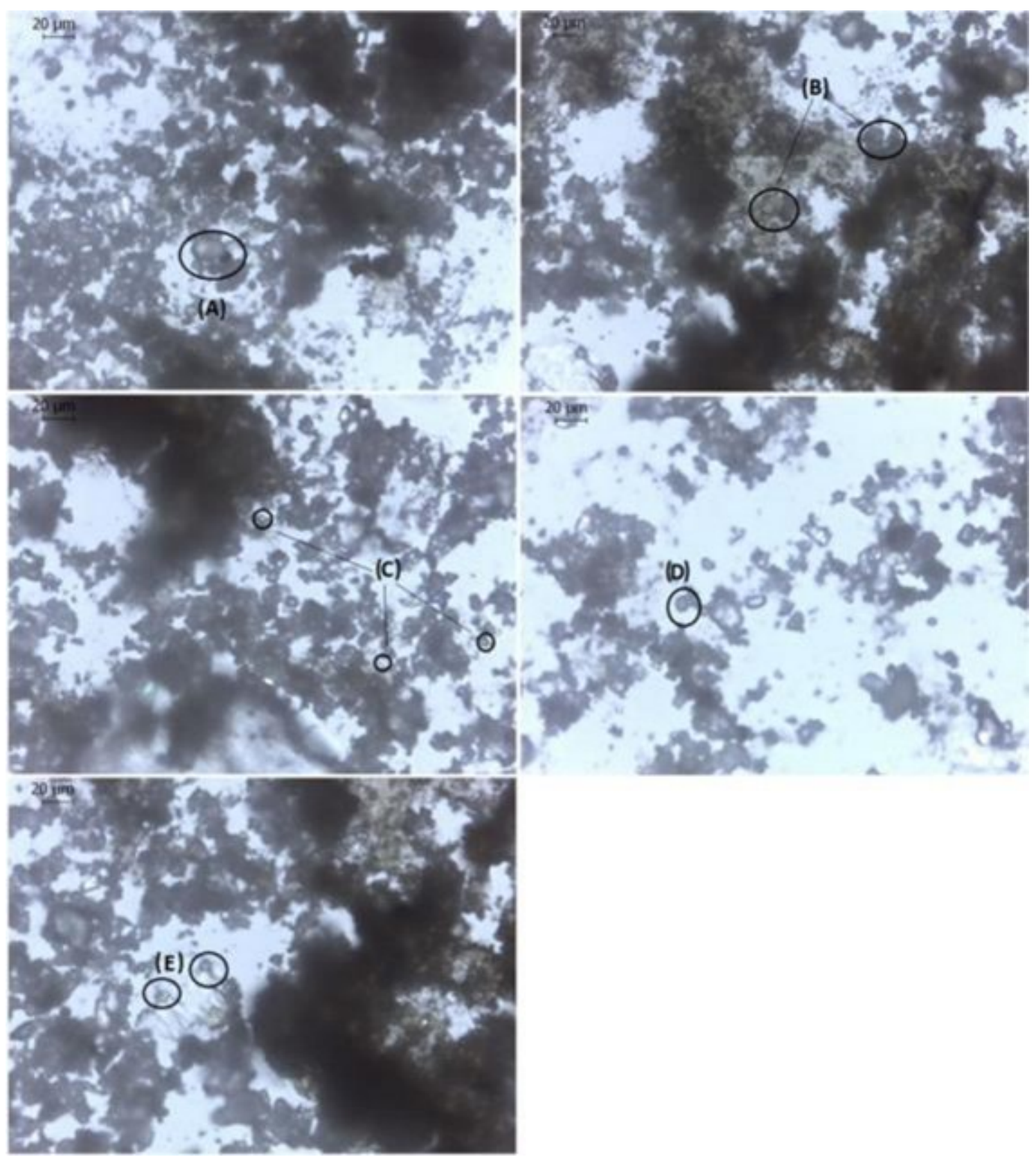

Figure 4. Identification of the main microbiological components in the material inside the dripper tubes operated with water with calcium: A) fecal coliforms; B) suggestive form of helminth egg; C) Microcystis aeruginosa; D) Suggestive of dinoflagellate; (E) Mite. 


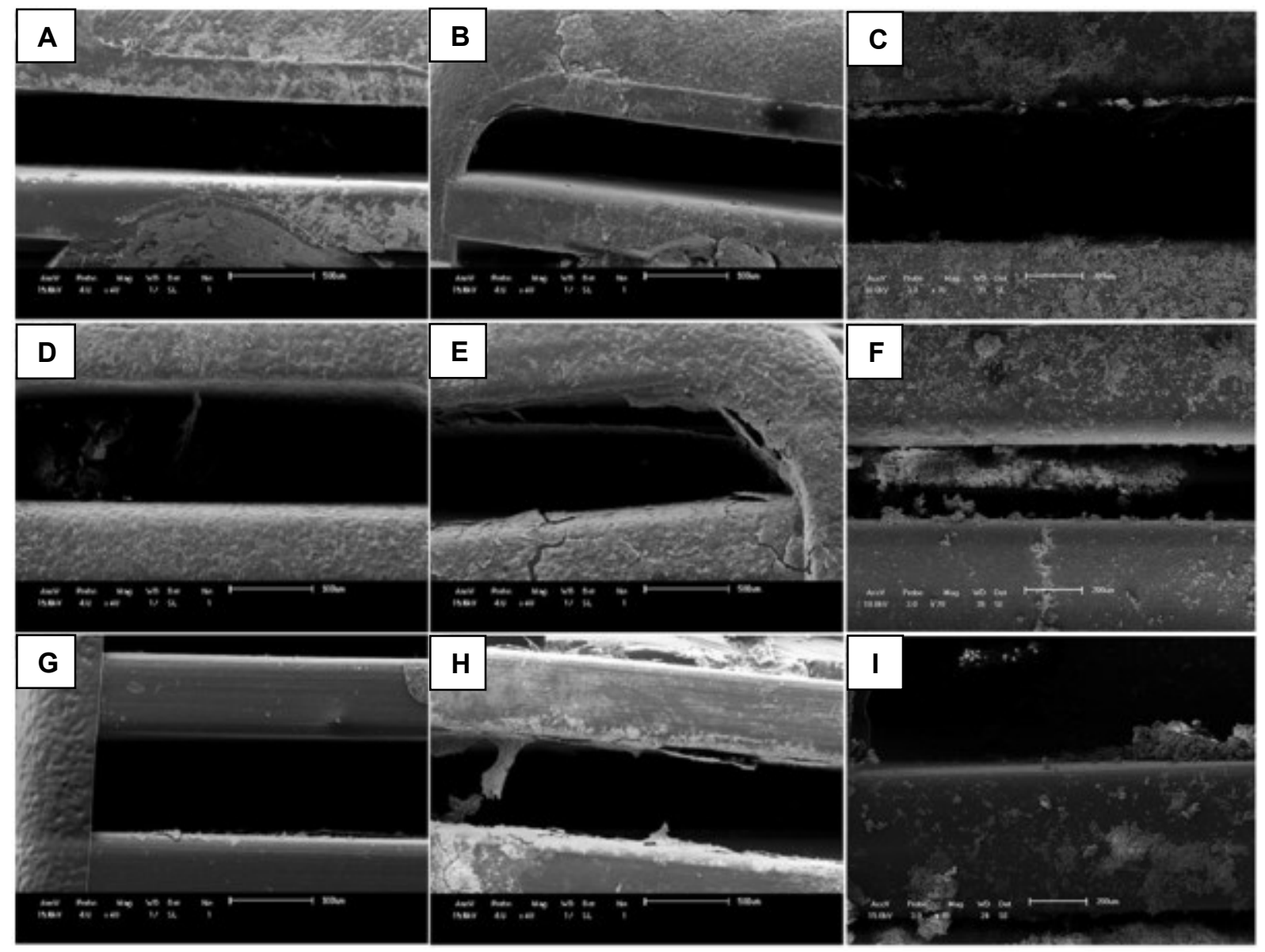

Figure 5. Scanning electron microscopy (SEM) images of the material adhered to the path walls of the dripper tubes Streamline (A, B, and C), Taldrip (D, E, and F), and Tiran (G, H, and I) operated with water supply (A, D, and G - 40x), wastewater $(\mathrm{B}, \mathrm{E}$, and $\mathrm{H}-40 \mathrm{x})$, and water with a high calcium content $(\mathrm{C}, \mathrm{F}$, and $\mathrm{I}-70 \mathrm{x})$.

Biofilm formations caused by bacterial colonies (Figure 5B, E, and $\mathrm{H}$ ) preclude water flow, causing a decreased dripper flow rate, thus affecting its hydraulic performance. According to Li et al. (2012), many bacteria such as coccus start forming colonies that aggregated on the wall of dripper tubes as aggregates of various sizes, changing their internal size, holes, and channels.

Another problem reported by Li et al. (2012), who used SEM, refers to biofilm deposit continuously at the entrance and exit of the path, resulting in emitter clogging. These authors observed that these aggregates could detach from the walls by becoming suspended and hence obstructing dripper holes.

SEM images were dried due to the requirements for analysis by this method. Thus, a reduction was observed in the biofilm of dripper walls, mainly in tubes operated with wastewater. For this reason, the presence of cracks in the biofilm was observed in the images (Figure 5B, E, and H).

According to Albuquerque, Andrade and Neves (2014), the biofilm extracellular matrix is produced by microorganisms. This polymeric matrix is known as extracellular polymeric substance (EPS) and consists of polysaccharides, proteins, exoenzymes, nucleic acids, and lipids, which allow immobilizing biofilm cells, keeping it cohesive. The basis of biofilm composition consists of the relations with carbon and oxygen, which have high rates of wastewater. Thus, wastewater has a great potential for clogging due to such characteristics.

Figure $5(\mathrm{C}, \mathrm{F}$, and $\mathrm{I})$ also shows the way in which the structures of the material deposited by water with calcium were formed. Unlike the water supply and wastewater, no biofilm was formed in the water with calcium, but the formation of structures with calcium precipitation.

According to Haman (2014), calcium carbonates readily precipitate in drip irrigation as they are in abundance in almost all water sources on the planet. Moreover, chemical reactions precipitate calcium, causing fouling in tube walls and drippers, thus leading to clogging.

In an experiment conducted by Tarchitzky et al. (2013), where fouling was analyzed in drip irrigation systems, calcium was found in large amounts. This shows the chemical reaction power of this type of element contained in water, being the main cause of fouling with precipitates in irrigation 
tubes, causing the clogging.

Figure 5 also shows a higher amount of material from the water with calcium deposited in the dripper Streamline (Figure 5C) when compared to Taldrip and Tiran (Figure 5F and I, respectively). In addition, precipitate and calcium deposits have the form of nodules adhered to tube walls, which can also detach, stay in suspension, and reach the dripper orifice, totally or partially obstructing it and affecting the hydraulic system performance. According to Liu and McAvoy (2015), this is recurrent in irrigation systems that use fertigation since fertilizers can react chemically, become insoluble, and precipitate, causing dripper clogging. Figure 6 shows how precipitate structures are deposited and form fouling on drip walls.
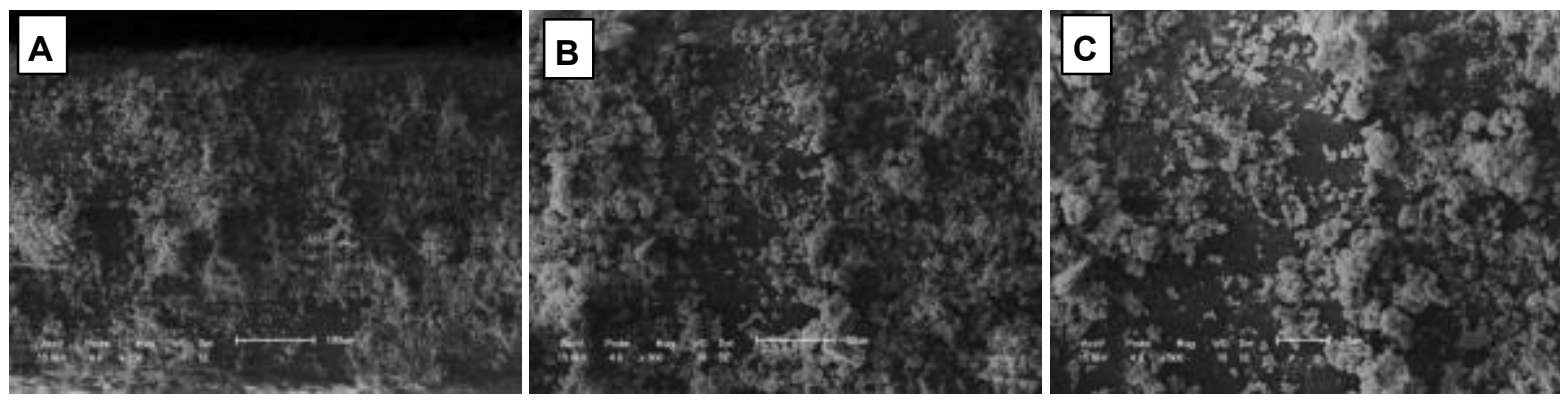

Figure 6. Details of clogging material on the wall of the dripper tube Streamline operated with water with calcium. Images magnified at 150x (A), 300x (B), and 500x (C).

In Figure 6A, precipitations of calcium chemical reactions covered practically all dripper surface, reducing the water flow area and directly affecting the hydraulic system performance. The structure in the form of nodules at different sizes and arrangements can be observed in Figure 6C causing a loss of load since it alters the roughness of the wall of tubes and paths of drippers, decreasing the flow rate. Another problem that may occur is the detachment of these particles from the dripper wall, reaching its orifice and causing its total or partial clogging.

Calcium carbonate precipitates are dependent on $\mathrm{pH}$ and temperature. Thus, any change in these factors can reduce calcium solubility in water and result in its precipitation (HAMAN, 2014).

\section{CONCLUSION}

Fouling was identified in drippers, indicating biofilm formation and precipitation of the chemical elements of calcium. These processes are different from each other, but both may cause dripper clogging.

Optical microscopy and scanning electron microscopy techniques allow a more detailed analysis of the clogging material in the biofilm and the chemical precipitate of calcium.

The main clogging material was probably calcium carbonate $\left(\mathrm{CaCO}_{3}\right)$ precipitation in water with a high calcium content and biofilm formation in wastewater from domestic sewage.

\section{REFERENCES}

ALBUQUERQUE, A. C.; ANDRADE, C.; NEVES, B. Biocorrosão - da integridade do biofilme à integridade do material. Corrosão e Proteção de Materiais, Lisboa, v. 33, n. 1-2, p. 18-23, 2014.

ALMEIDA, O. A. Qualidade de água para irrigação. 2. ed. Cruz das almas, BA. EMBRAPA mandioca e fruticultura, 2010. 227p.

ARAGUÉS, R. et al. Calidad de água para Riego. I. Criterios generales. Informacion tecnica economica agraria, Zaragoza, v.1, n. 37. p. 3-17. 1979.

AYERS, R. S., WEStCOT, D. W. A qualidade de água na agricultura. Tradução de H. R. GHEYI; J. F. MEDEIROS; F. V. A. DAMASCENO. 29. ed. Campina Grande, PB. UFPB, 1991. 208 p. (Estudos FAO: Irrigação e Drenagem).

BATISTA R. O.; SOUZA J. A. R.; FERREIRA D. C.; Influência da aplicação de esgoto doméstico tratado no desempenho de um sistema de irrigação. Revista Ceres, Viçosa, MG, v. 57, n. 1, p. 18-022, 2010 .

CAVALCANTE, L. F. Sais e seus problemas nos solos irrigados. 1. ed. Areia, PB: Centro de Ciências Agrárias, UFPB, 2000. 71 p.

GHUNMI, L. A. et al. Grey water treatment in a series anaerobic - aerobic system for irrigation. Bioresourse Technology, Amann, v. 101, n. 1, p. 41 $-50,2009$.

HAMAN D. Z. Causes and Prevention of Emitter Plugging In Microirrigation Systems. Gainesville, FL, Séries: BUL258, Agricultural and Biological Engineering Department, UF/IFAS Extension. 
October 2014 .

HERRMANN, P. S. P. et al. Analysis of spatial variability of lyosozyme thin film by AFM. Acta Microscopica, Rio de Janeiro, v. 6, s/n., p. 290-291, 1997.

LI, Y. K. et al. Surface topographic characteristics of suspended particulates in reclaimed wastewater and effects on clogging in labyrinth drip irrigation emitters. Irrigation Science, v. 30, n. 1, p. 43-56, 2012.

LIU, G.; MCAVOY, G.. How to Reduce Clogging Problems in Fertigation. 2. ed. Gainesville, FL, series of the Horticultural Sciences Department, UF/ IFAS Extension, 2015. 6 p

MENEZES, M. AND BICUDO, C. E. M. Lista de espécies: algas. In: FORZZA, R. C. Catálogo de plantas e fungos do Brasil. 1. ed. Rio de Janeiro, RJ, Andrea Jakobsson Estúdio, v. 1, 2010. p. 262451.

NAKAYAMA, F. S., BUCKS, D. A. Trickle irrigation for crop production: Design, operation and management. Amsterdam: Elsevier Science, 1986. 383 p.

NAKAYAMA, F. S. Water analysis and treatment techniques for control emitter plugging. In: Proceedings Irrigation Association Conference, 1982, Portland, Oregon, 1982. p. $97-112$.

PIZARRO, F. Riegos localizados de alta frecuencia (RLAF). Goteo, microaspersíon y exudación. 3 ed. Ver. Y amp. Madrid: Mundi-Prensa. 1996. 513 p.

SILVA, I. N. et al. Qualidade de água na irrigação. Revista: Agropecuária Científica no Semi-áridoACSA, Campina Grande, v. 7, n. 3, p. 1 - 15. 2011.

SANT'ANNA, J. P. Nanotecnologia minúsculas partículas, grandes negócios. Revista Química e Derivados, v. 443, p. 14-26, dezembro de 2005. Disponível em: $<$ http://www.quimica.com.br/> Acesso em: 08 mar. 2016.

SCHONHERR, H.; VANCSO, G. B.; ARGON, A. S. The Structure of Highly Textured Quasi-Single Crystalline High-Density Polyethylene Probed by Atomic-Force Microscopy and Small-Angle X-RayScattering, Polymer, Great Britain, v. 36, n. 11, p. 2115-2121. 1995.

TARCHITZKY, J. et al. Biological and chemical fouling in drip irrigation systems utilizing treated wastewater. Irrigation Science, Amsterdam, v. 31, n. 6, p. $1277-1288,2013$.

TOMA, H. E.; ARAKI, K. Nanociência e nanotecnologia: o gigantesco e promissor mundo do muito pequeno. Ciência Hoje, vol. 37, n. 217, p. 25, junho de 2005. Disponível em: <http:// cienciahoje.uol.com.br/3440> Acesso em: 08 mar. 2016.

VALE, H. S. M. et al. Potencial de entupimento de um sistema de irrigação por gotejamento operando com esgoto doméstico tratado. Water Resources and Irrigation Management, Campina Grande, v. 2, n. 1, p. 63-70, 2013. 